\title{
Evaluation of reservoir compartmentalization and property trends using static modelling and sequence stratigraphy
}

\author{
Chinazo F. Ejeke ${ }^{1} \cdot$ Emmanuel E. Anakwuba $^{1} \cdot$ Indutimi T. Preye ${ }^{2}$. \\ Omagbemi G. Kakayor ${ }^{2} \cdot$ Ime E. Uyouko ${ }^{2}$
}

Received: 29 June 2015/Accepted: 1 August 2016/Published online: 15 October 2016

(c) The Author(s) 2016. This article is published with open access at Springerlink.com

\begin{abstract}
In the context of harder-to-find reserves and rise in development costs, it is vital that reservoir heterogeneities and compartmentalization be accurately predicted ahead of the drill bit. There are many situations where unexpected compartmentalization negatively impacts reservoir development. This paper used an integration of 3D seismic, well logs, and biostratigraphic data analysis to evaluate compartmentalization in a low well density reservoir (Z-2), onshore Niger Delta. The aim was to identify areas of bypassed hydrocarbon accumulations during production due to compartmentalization. Structural modelling of the Z-2 reservoir identified three intra-reservoir faults that could lead to possible compartmentalization of the reservoir. Z-2 reservoir was interpreted as early transgressive systems tract normal regressive sediments
\end{abstract}

Chinazo F. Ejeke

ejekechin@gmail.com

Emmanuel E. Anakwuba

ek.anakwuba@unizik.edu.ng

Indutimi T. Preye

indutimi.preye@shell.com

Omagbemi G. Kakayor

omagbemi.kakayor@shell.com

Ime E. Uyouko

Ime.IU.Uyouko@pdo.co.om

1 Department of Geological Sciences, Nnamdi Azikiwe University, Awka, Nigeria

2 Shell Nigeria, PortHarcourt, Nigeria based on sequence stratigraphic techniques used in the modelling. Z-2 reservoir is bounded below and above by layers of shale about $180-200 \mathrm{ft}$ thick, which provides a good seal for the reservoir. Sequential Gaussian simulation algorithm was used to distribute the modelled petrophysical properties in the static model. Modelled porosity, permeability, and NTG ranges are 5-30\%, 1-10,000 mD, and $0.10-0.98$, respectively, through all layers. Z-2 reservoir was divided into two flow units separated by approximately 12-ft-thick shale unit, which could act as a barrier to flow between the zones. Fault analysis was done using Shell structural and fault analysis plug-in in Petrel to determine the shale gauge ratio, fault permeability, and fault zone thickness of the relevant intra-reservoir faults. Fault juxtaposition analysis shows sand-on-sand juxtaposition at the fault tips. Further analysis shows that fault thickness is within the gas crossflow range of $(0-0.6 \mathrm{ft})$ and shale gouge ratio for all three faults falls within the ranges of $0-100 \%$ with a significantly higher percentage of the areas below $35 \%$ in fault 3 . Fault 1 will not allow gas crossflow, while $<20 \%$ of the juxtaposed areas in fault 2 are within the range to permit gas crossflow. Fault 3 which has a low SGR and high permeability relative to the other faults is not interpreted to be sealing. Fault zone permeability for parts of fault 1 is $<1 \mathrm{mD}$ while parts of faults 2 and 3 are $>1 \mathrm{mD}$. The Z-2 reservoir stands the risk of being compartmentalized into two hydrocarbon accumulations (' $\mathrm{X}$ ' and ' $\mathrm{Y}$ ') during production. The total GIIP for Z-2 is 1668 Bscf and with the present well positions and configurations; the production of about $20 \%$ of the GIIP is at risk of being bypassed. Future wells should be planned to appraise ' $\mathrm{X}$ ' and ' $\mathrm{Y}$ ' accumulations.

Keywords Niger Delta - Reservoir compartmentalization · 3D seismic $\cdot$ Static modelling 


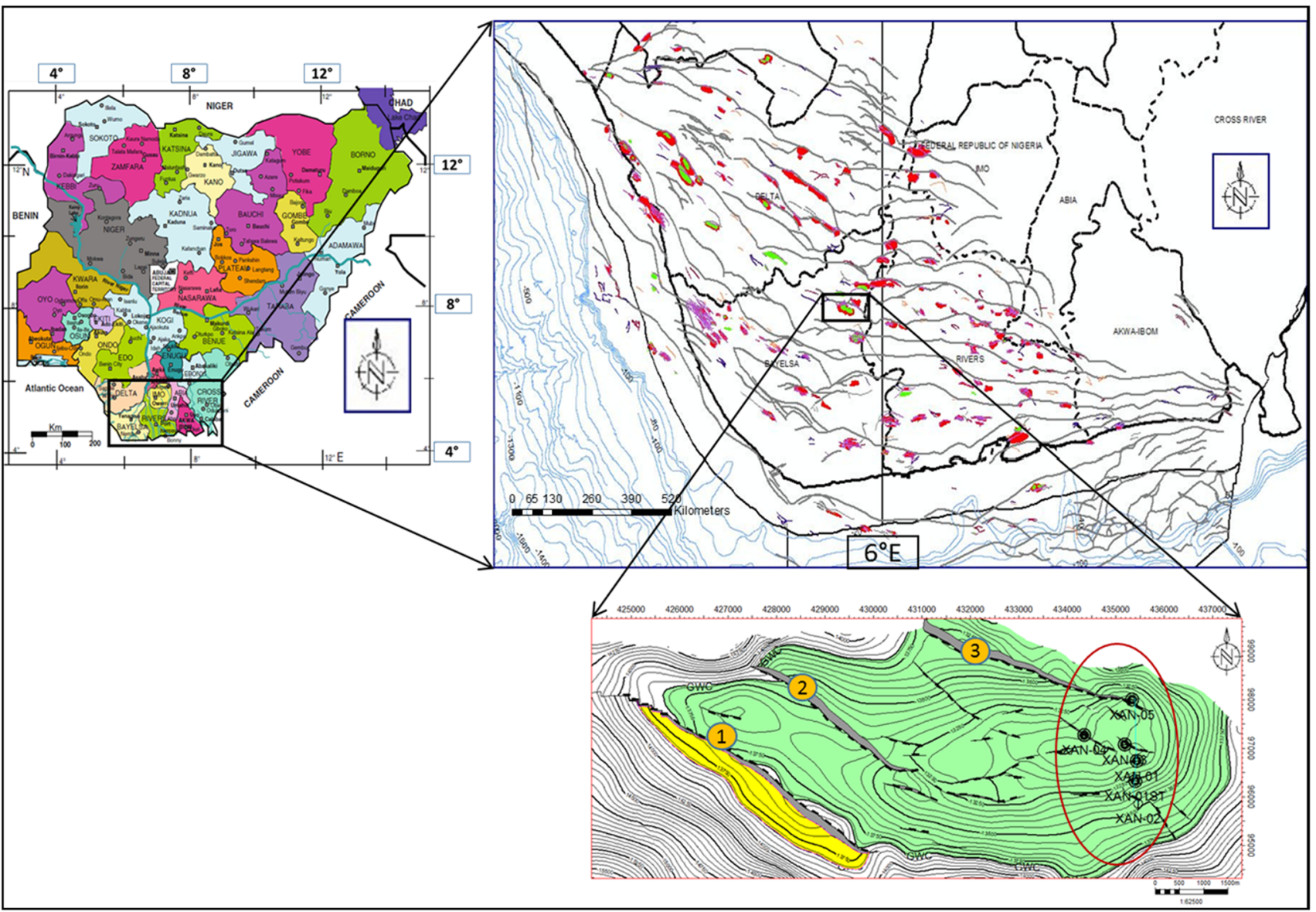

Fig. 1 Map of the Niger Delta with the X-field (highlighted with a black rectangle) and Z-2 (highlighted with red rectangle). Well points are highlighted on Z-2 surface map showing the close cluster of the

\section{Introduction}

Reservoir compartmentalization is the segregation of petroleum accumulation into a number of individual fluid or pressure compartments by bounding features which prevent hydrocarbon crossflow (Caine et al. 1996). These features are seals and may be of two types: static seals which are capable of holding petroleum over geologic time and dynamic seals that are low to very low permeability flow baffles. Dynamic seals can reduce petroleum crossflow to infinitesimally slow rates, and allow fluids and pressures to equilibrate over geological timescales, but act as seals over production timescales (Jolley et al. 2010). Reservoir compartmentalizing features are also classified into tectonic, stratigraphic, or a combination of both, according their origin. Tectonic generated features include folds, faults, fractures, and diapirs (salt and shale), which confine hydrocarbon. Faults can separate reservoirs into compartments, particularly when a fault offset juxtaposes sandstone against shale or a significant amount of fault gouge within the fault zone during faulting. The industry's knowledge of existing wells at the far eastern region of the reservoir. This leaves the middle and western regions devoid of well control. The area coloured yellow represent volume of gas not tested by any well

sealing potential of faults in the Niger Delta is mainly based on information about normal faults (Bretan et al. 2003). In general, the maximum seal capacity of a fault is directly proportional to the shale gouge ratio (SGR) and is inversely proportional to the net-to-gross (NTG) ratio of the faulted section (Smith 1980; Yielding et al. 1997; Bretan et al. 2003). Stratigraphic compartmentalizations are caused by stratigraphic heterogeneities and can be classified into microscopic (pore/grain-scale), mesoscopic (well-scale), and macroscopic (interwell-scale) heterogeneities (Krause et al. 1987) based on the types and scales of the heterogeneities. Interwell-scale heterogeneities include lateral bed discontinuity as a result of stratigraphic pinch-out and erosional cut-out.

Unexpected compartmentalization may introduce inaccuracies in reserve booking, reduce field profitability, and result in unexpected high costs of operation, inaccurate enhanced recovery planning, and early field abandonment (Knott 1993; Leveille and Knipe 1997; Hesthammer et al. 2002). These problems are exaggerated at reservoirs with fewer wells, and unfortunately the negative effects are 
often realized through experience relatively late in production life of reservoirs (Gainski et al. 2010). Successful field appraisal and production optimization can be achieved through accurate characterization and prediction of reservoir compartmentalization and its effects on fluid flow (Barkved et al. 2003).

Irving et al. 2010 noted that a key problem for fluid flow modelling in petroleum reservoirs is that the subsurface data used to populate models are limited to low-resolution seismic data or sparse high-resolution well data. Jolley et al. (2007a, b) agree that structural configuration, depositional architectures, and fault juxtapositions define the basic 'plumbing' of a reservoir. Therefore, it is important in evaluating reservoirs, to integrate well and seismic data for a robust interpretation; this is critical for understanding and reliably modelling reservoir compartmentalization especially with low well control.

The aim of this paper is to evaluate the level of compartmentalization in the Z-2 reservoir by building a representative 3D static model, using sequence stratigraphy to predict reservoir properties and spatial geometries. These properties include facies, porosity, permeability, and water saturation. Fault analysis was also performed to identify fault-related compartmentalization in the Z-2 reservoir in order to reduce risk of bypassed hydrocarbon during production, proper placement of production wells, and optimum determination of completion intervals, reservoir prediction and development.

\section{The study area}

Z-2 reservoir is located in the Central Swamp Depobelt of the wave- and tide-dominated Niger Delta basin in the Gulf of Guinea, which shows a shallowing-upward trend from marine to continental facies (Fig. 1) (Doust and Omatsola 1990). The Niger Delta is divided into the Akata, the Agbada, and the Benin formations (Short and Stauble 1967; Avbovbo 1978; Doust and Omatsola 1990; Kulke 1995). The Akata Formation at the base of the delta is of marine origin and is composed of thick shale sequences (potential source rock), sandy turbidite (potential reservoirs in deep water), and minor amounts of clay and silt. The overlying the Akata Formation consists of 3700-m-thick paralic siliciclastics and represents the actual deltaic portion of the sequence. In the lower Agbada Formation, shale and sandstone beds were deposited in equal proportions; however, the upper portion is mostly sand with only minor shale interbeds. The Agbada Formation is overlain by the Benin Formation, a continental Late Eocene to recent

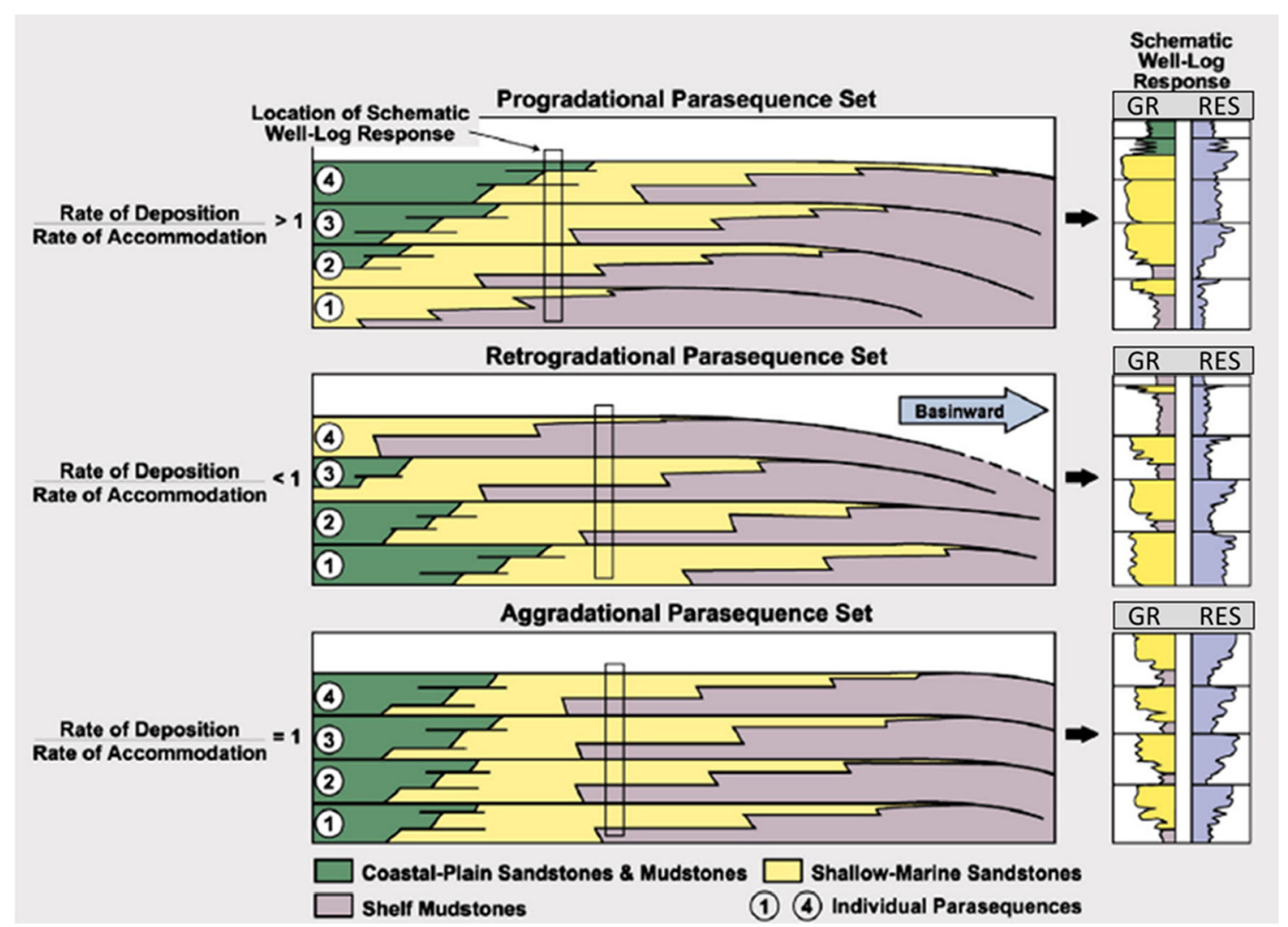

Fig. 2 Vertical stacking of parasequence sets (modified from Van Wagoner et al. 1990) 


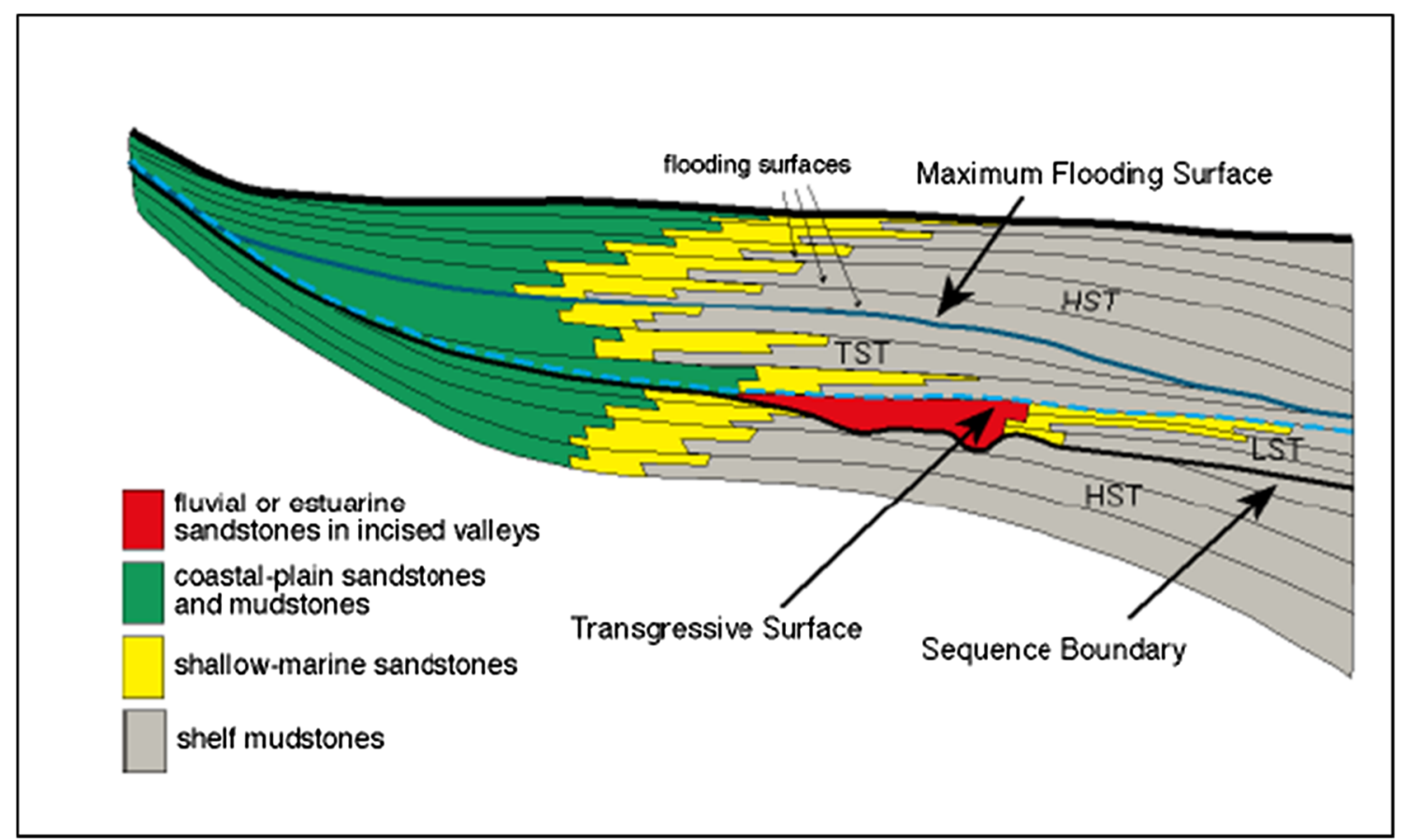

Fig. 3 Depositional sequences and the key vertical succession

deposit of alluvial and upper coastal plain sands that are up to $2000 \mathrm{~m}$ thick (Avbovbo 1978).

The Z-2 reservoirs length is estimated at $16 \mathrm{~km} \mathrm{E-W,}$ and $6 \mathrm{~km} \mathrm{~N}-\mathrm{S}$. There has been no production from the reservoir. Six wells exist in the Z-2 reservoir all located at the eastern part.

\section{Data and methodology}

Data available for this study include a 3D seismic volume (prestack depth migrated), consisting of 1153 inlines and 422 crosslines with good reflections, and six wells with a suite of well logs such as gamma ray, resistivity, neutron, and density logs (only for wells XAN-01 and XAN-01ST). Palaeobathymetric and biofacies data are available for one well XAN-01. All wells are drilled to the eastern region of the reservoir (Fig. 1). In addition, checkshots and seismic inversion were used to provide net-to-gross (NTG) and porosity maps.

Lithostratigraphic correlation was done based on well logs. Top and base of the Z-2 reservoir were identified in all wells except for XAN-03 and XAN-04 that were base faulted.

A well-to-seismic tie was done to identify the reservoir on seismic. This was aided by a synthetic seismogram that was generated by convolving an extracted seismic wavelet with acoustic impedance $\log$ at the wells. The seismic volume was interpreted by digitizing along the inline and crosslines to obtain the reservoir grid from which the reservoir top structural map was generated. A semblance attribute volume was generated from the available seismic data and used to identify and interpret the faults associated with the Z-2 reservoir.

Two velocity models were generated using the available checkshots: $V_{0}$ and $K$ constant model $\left(V_{0} K\right)$, and a polynomial model. The $V_{0} K$ model proved to be more robust with a least average and standard deviation of residuals. Therefore, the $V_{0} K$ model was used to convert the interpreted faults and surfaces from time to depth.

Sequence stratigraphic analysis was carried out based on biostratigraphic data (pollen and foraminifers), depositional environments, and well logs (gamma ray, resistivity, neutron, and density) in the XAN-01 well. Plots of pollen and foraminiferal abundant and diversity in Petrel helped to identify the maximum flooding surfaces (MFS candidates) in the well. The MFSs were identified at depths with a relative high abundance and diversity of pollen and forams. These depths were confirmed by wide separation of neutron and density logs (high density and high neutron count), low resistivity reading, and high gamma ray count. MFSs are horizons of maximum transgression within a sequence (Van Wagoner et al. 1990).

Sequence boundaries are defined as unconformities, landward or basinward correlative conformities that are laterally continuous over at least the basin scale and separates older underlying sediments from younger overlying sediments by a significant depositional hiatus. They are 


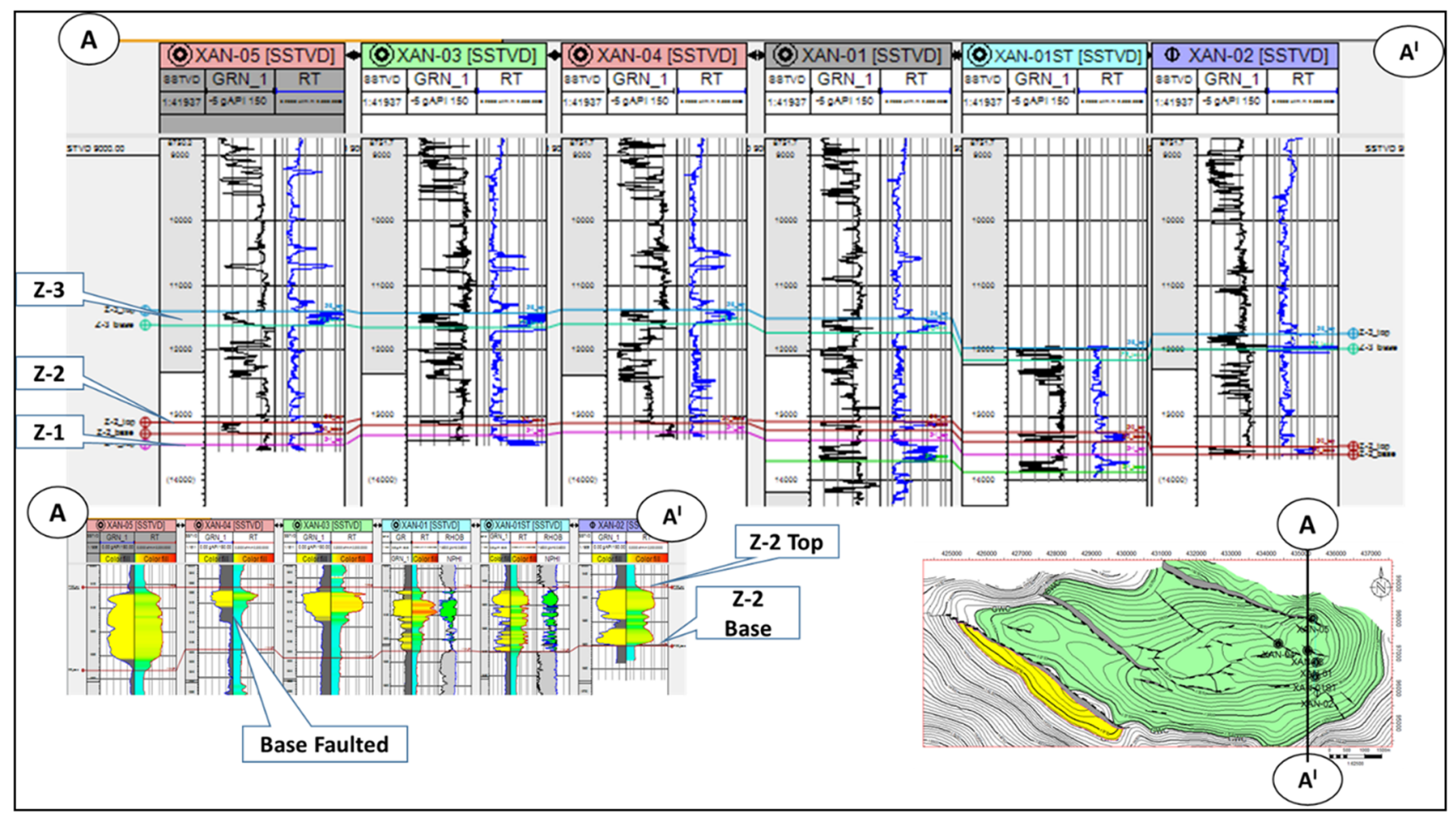

Fig. 4 Field wide dip section correlation of Z-1, Z-2, and Z-3 reservoirs. A slight upstepping of Z-2 between XAN-05 and XAN-04 suggests an antithetic fault between the wells. Wells XAN-03 and XAN-04 are base faulted so do not reflect facies change across well points

identified in well logs, by one or more of the following criteria:

(1) Subaerial erosional truncation (channel incision), laterally equivalent subaerial exposure surfaces (developed palaeosol profiles), and downdip submarine erosion;

(2) Change from prograding parasequence set stacking pattern to retrograding parasequence set stacking pattern;

(3) Basinward shift in environments (landward facies directly overlying basinward facies with no intermediate environments in between; (Van Wagoner et al. 1990).

The parasequence boundaries were identified as flooding surfaces with overlying facies showing a deepening of depositional setting. Parasequence stacking patterns are responsive to variations of sediment supply and accommodation (Fig. 2). Parasequences may stack into landwardstepping retrogradational sets, aggradational sets, and basinward-stepping progradational parasequence sets which belong to various forms of systems tracts (Fig. 2). The lowstand systems tract (LST) is identified to be bounded below by a sequence boundary and above by an initial flooding surface, and contains progradational or aggradational parasequence stacking patterns. The transgressive systems tract (TST) is bounded below by the initial flooding surface and above by the maximum flooding surface, and contains retrogradationally stacked parasequences. Finally, the highstand systems tract (HST) is bounded below by the maximum flooding surface and above by a sequence boundary, and consists of aggrading or prograding parasequence stacking patterns (Van Wagoner et al. 1990; Posamentier and Allen 1999). Systems tracts are arranged LST, TST, and HST through one depositional sequence (Fig. 3). The stacking trends were used to delineate sequence stratigraphic surfaces and the stacking patterns used to identify systems tracts, and define stratigraphic sequences (Fig. 3).

Structural modelling defined the geometry of the Z-2 reservoir. The fault framework was modelled by reconstructing the faults using the interpreted fault sticks from seismic interpretation. The interpreted faults were converted to fault planes using the Petrel fault modelling process. The major and minor fault planes were created and the boundaries of the reservoir defined in a three-dimensional model. The modelled faults were used as key pillars in gridding the reservoir into geocellular blocks of $50 \times 50 \mathrm{~m}$ each in the $x(i)$ and $y(j)$ directions. A total of 486,720 grids cells were created over the reservoir area.

The stratigraphic modelling was carried out after successful pillar gridding of the fault blocks. The interpreted reservoir top and base were used as bounding surfaces for stratigraphic modelling. Thicknesses at well points were

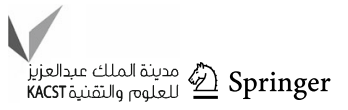




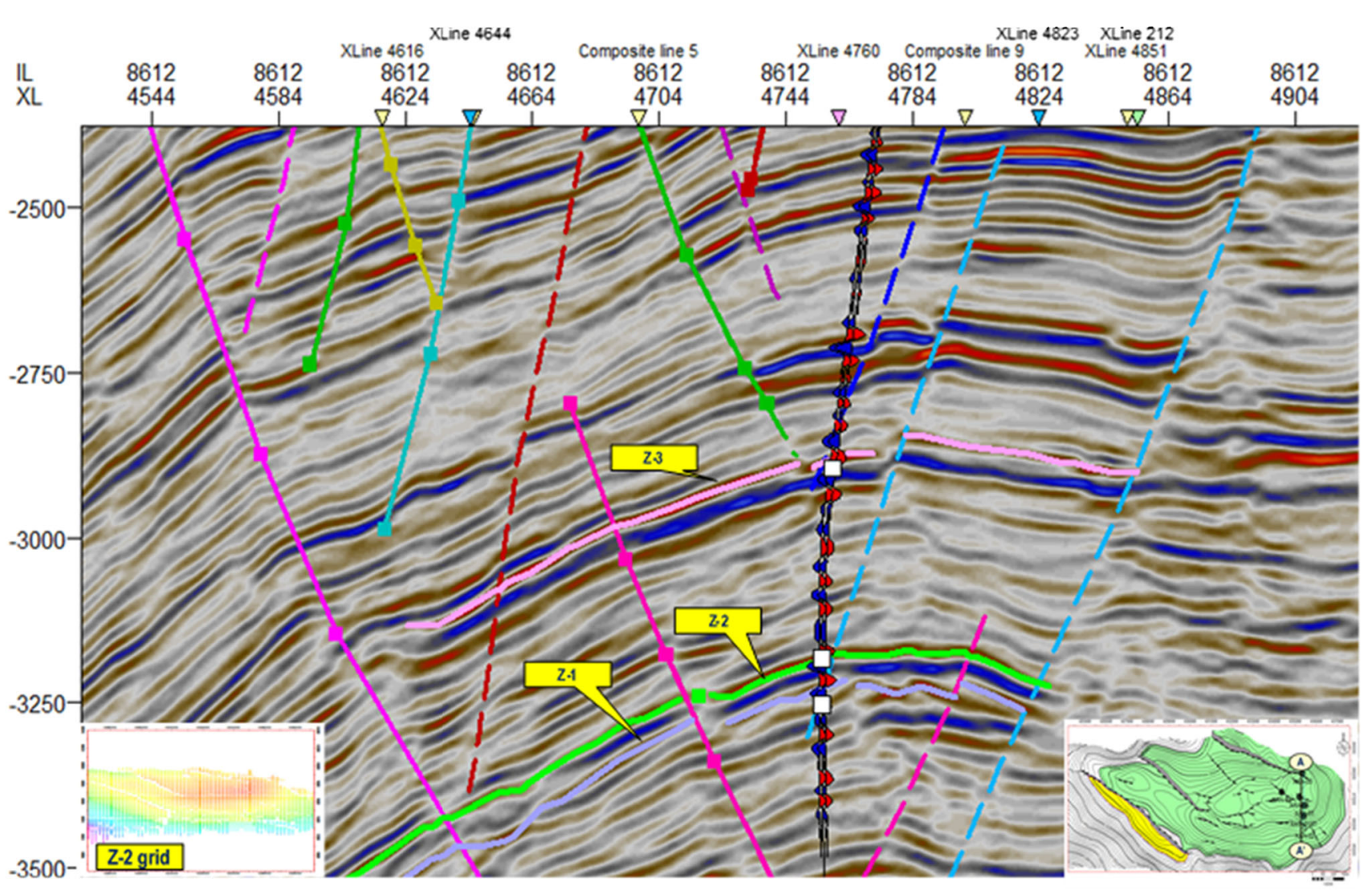

Fig. 5 Inline (8612) section showing the interpreted Faults and horizons (Z-1, Z-2, and Z-3). The synthetic seismogram is well tied at the Z-2 layer of interest. Horizons Z-1 and Z-3 were interpreted to provide stratigraphic control

used as seeded values for convergence interpolation algorithm to generate the reservoir thickness. The reservoir was subdivided into the major stratigraphic zones and layers of cells with different geometries in relation to the bounding surfaces. Horizon and layer models were built by generating surfaces within each zone, which represent the main geological horizons, consistent with the depths observed in available wells and interpreted in flow unit description.

The facies descriptions at wells were done using the gamma ray signatures to define the facies. The facies were then used to generate a 3D distribution of facies by applying stochastic algorithm - sequential indicator simulation (SIS), with the 3D structural model as a base. The stochastic modelling method was used as opposed to deterministic method because of sparse well distribution over the Z-2 reservoir. SIS calculated stochastic realizations of the facies properties based on the upscaled definition of facies and variogram settings were based on the Niger Delta facies descriptions.

Petrophysical property (NTG, porosity, and permeability) models were generated by a weighted interpolation of the properties across the grids as a function of defined facies, honouring the facies models. Stochastic control was applied in property modelling by constraining the modelled properties with well body volumes and inversion products (porosity and permeability maps).
Faults are 3D zones of strain that develop during the formation of a fault through its periods of propagation, linkage, and slip consolidation (Wibberley et al. 2008). These fault zones are composed of disarranged and reaggregated fragments of the host rock lithostratigraphy (Foxford et al. 1998; Aydin and Eyal 2002). The total flow retarding effect of a fault is caused by the distribution, rearrangement, and juxtapositions of lithological fragments, and thus, permeability collapses within faulted rocks. Fault analysis for the Z-2 reservoir was done on the intra-reservoir faults 1, 2, and 3 using the STAR plug-in in Petrel. This uses faults, horizons, and zones from 3D seismic and well logs to generate framework scenarios based on structural uncertainty. It determines the structural spill point for each horizon scenario at all reservoir levels and generates the SGR to locate the leak zones for faults. Fault juxtaposition analysis is used to determine sand-onsand juxtaposition and possible gas crossflow at the faults. Yielding et al. (2010) and Onyeagoro et al. (2001) suggest that an effective crossflow across faults in a gas reservoir should have reservoir permeability $(K)$ about $1 \mathrm{mD}$, fault zone thickness between 1 and $20 \mathrm{ft}$, fault zone permeability $(K)>1 \mathrm{mD}$ and SGR $<30 \%$. Fault permeability, SGR, and thickness analysis were carried out to evaluate the sealing potentials of the faults. 


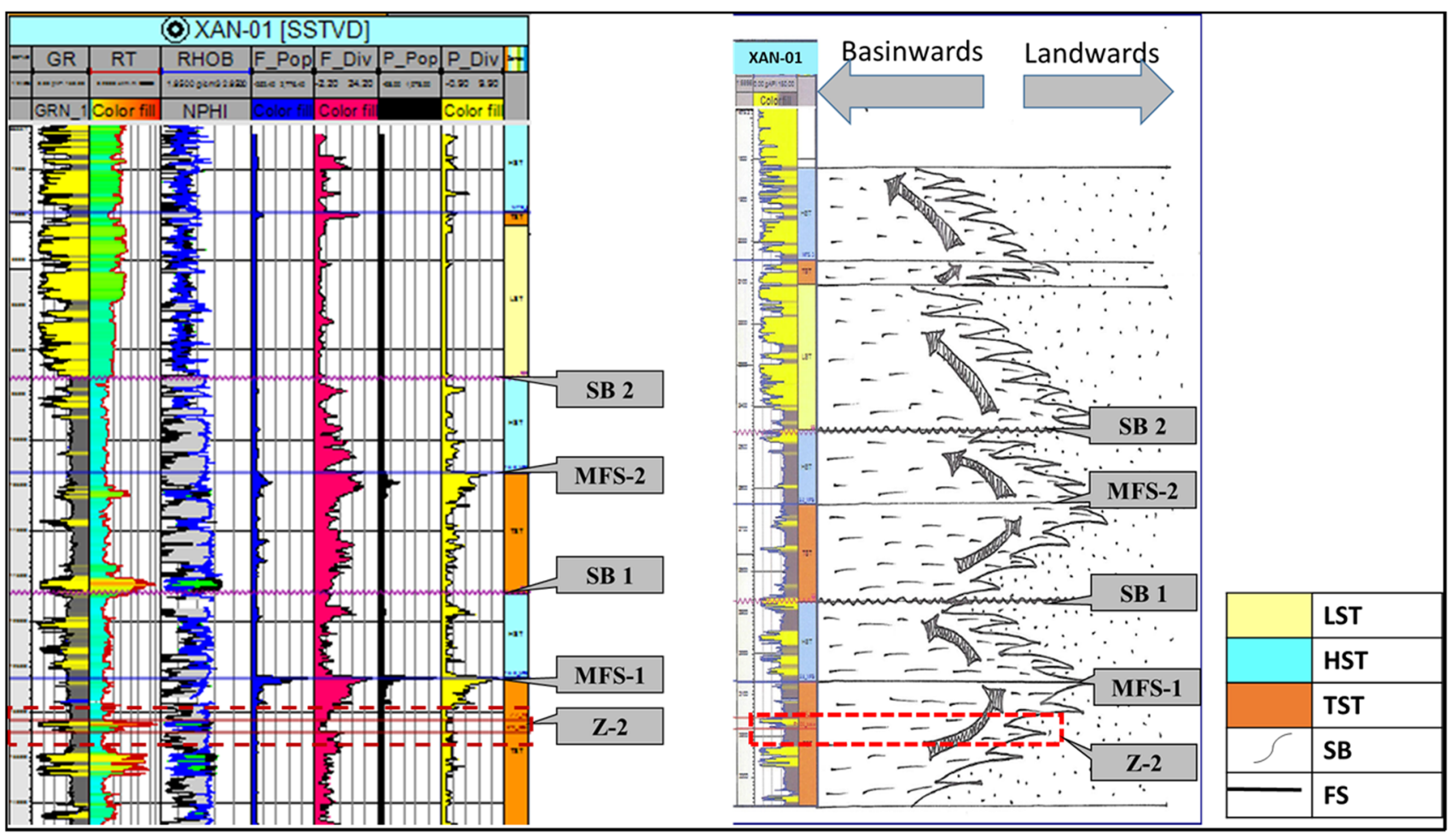

Fig. 6 A third-order (well-scale) sequence stratigraphic analysis. Three associated system tracts (HST, LST, and TST) were identified based on electrofacies. Z-2 is shown to be deposited in a regressive phase of a transgressive systems tract

Fig. 7 A schematic facies spatial geometries based on sequence stratigraphic interpretation at well XAN-01. $\mathrm{XAN}-01$ did not encounter an LST before SB-1 likely because the LST is deposited further basinwards as a basin floor fan as shown

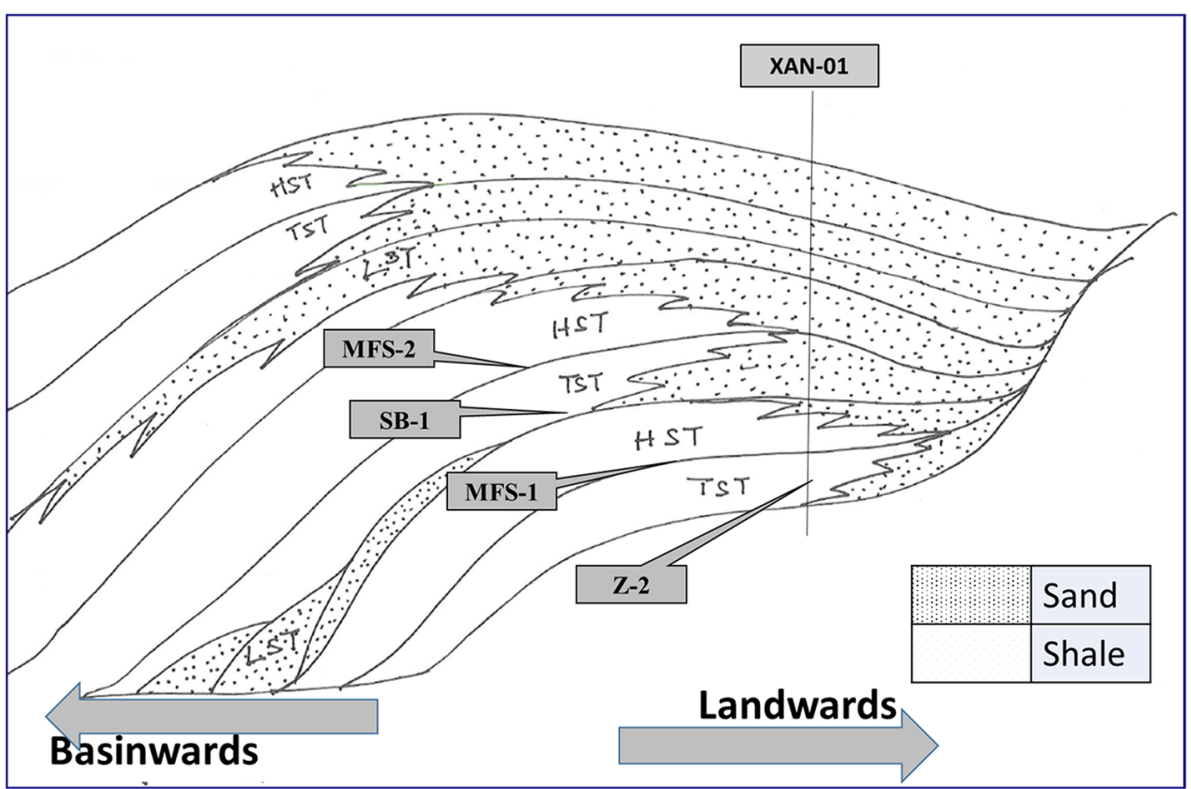

\section{Uncertainties}

A major uncertainty is the net rock volume. The well control points are few and not evenly distributed over the reservoir; therefore, the constructed facies model will have limitations in predicting reservoir geometries. Prediction was, however, guided with the sequence stratigraphy analysis results. Uncertainty in facies modelling was handled by creating two facies scenarios: one with more channels and another with fewer channels during modelling. The results show no discernible difference in volume calculations and fault analysis results. Uncertainty in petrophysical property modelling is linked to facies modelling as the properties were based on the facies. 


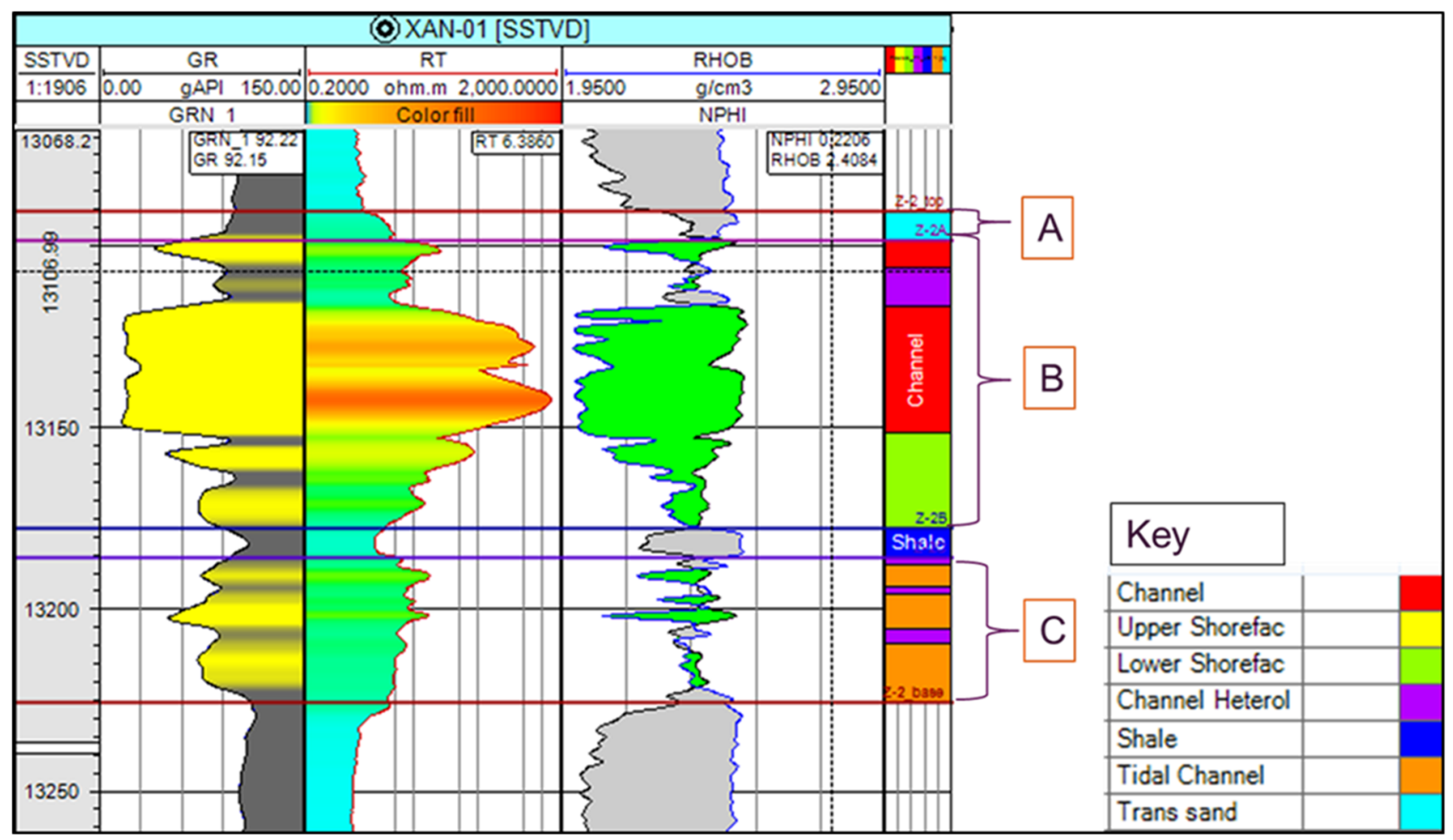

Fig. 8 Intra-reservoir facies description for the XAN-1 well. Three facies zones $(A, B$, and $C)$ and a shale unit were described for the reservoir. Facies are attributed to channels, lower shoreface, channel heteroliths, tidal channel

\section{Results and discussion}

\section{Reservoir correlation}

Correlation of reservoirs Z-1, Z-2, and Z-3 shows downstepping and basinward deterioration of the reservoir quality. This is attributed to deposition of sandy reservoirs in a regressive phase. Thickness variation and net sand distribution along wells can be observed in different parts of fluvial-marine depositional environment. The general reservoir thickness along correlation path ranges from $175 \mathrm{ftss}$ (feet subsea) at the north to $125 \mathrm{ftss}$ southwards. This is caused by a gradual termination of the continental processes from the north to the south, landwards to basinwards, in a regressive phase. A relative slight upstepping of the Z-3 reservoir indicates the presence of an antithetic fault between wells XAN-01ST and XAN-02 (Fig. 4). Facies encountered by Wells XAN-04 and XAN-03 are base faulted and not representative of the facies change along well points across the reservoir (Fig. 4). Therefore, these wells were not used in facies and zone description.

\section{Seismic Interpretation}

A network of synthetic faults dipping seawards and antithetic faults dipping landwards were interpreted from the seismic. The reservoir structural top is a fault assisted dip closure. Z-2 is bounded to the north by a major synthetic growth fault. It has a low relief crest but with steeper flanks. The major and minor intra-reservoir faults trend generally along the regional structural strike along the east-west direction (Fig. 5).

\section{Sequence stratigraphic analysis}

Two MFS candidates, MFS-1at 12,624 ft and MFS-2 at 10,349 ft (Fig. 6), were identified on the wireline logs and biostratigraphic data, at the boundary between retrogradational and progradational parasequence sets. The MFSs occur between facies units with well-developed shales (shaliness) visible on the GR, resistivity and neutron logs, and as a surface of maximum pollen and foraminiferal abundance and diversity.

Two sequence boundaries (SB), SB1 at $11,577 \mathrm{ft}$ and SB2 at $9282 \mathrm{ft}$, were interpreted as surfaces of low faunal abundance and diversity or absence of known bioevents. These depths corresponded to low gamma ray and high Resistivity logs responses within the shallowing section. These depths also occur at the base of thickest and coarsest sandy units between two adjacent MFSs (Fig. 6), which naturally coincided with the least foraminiferal abundance and diversity. 


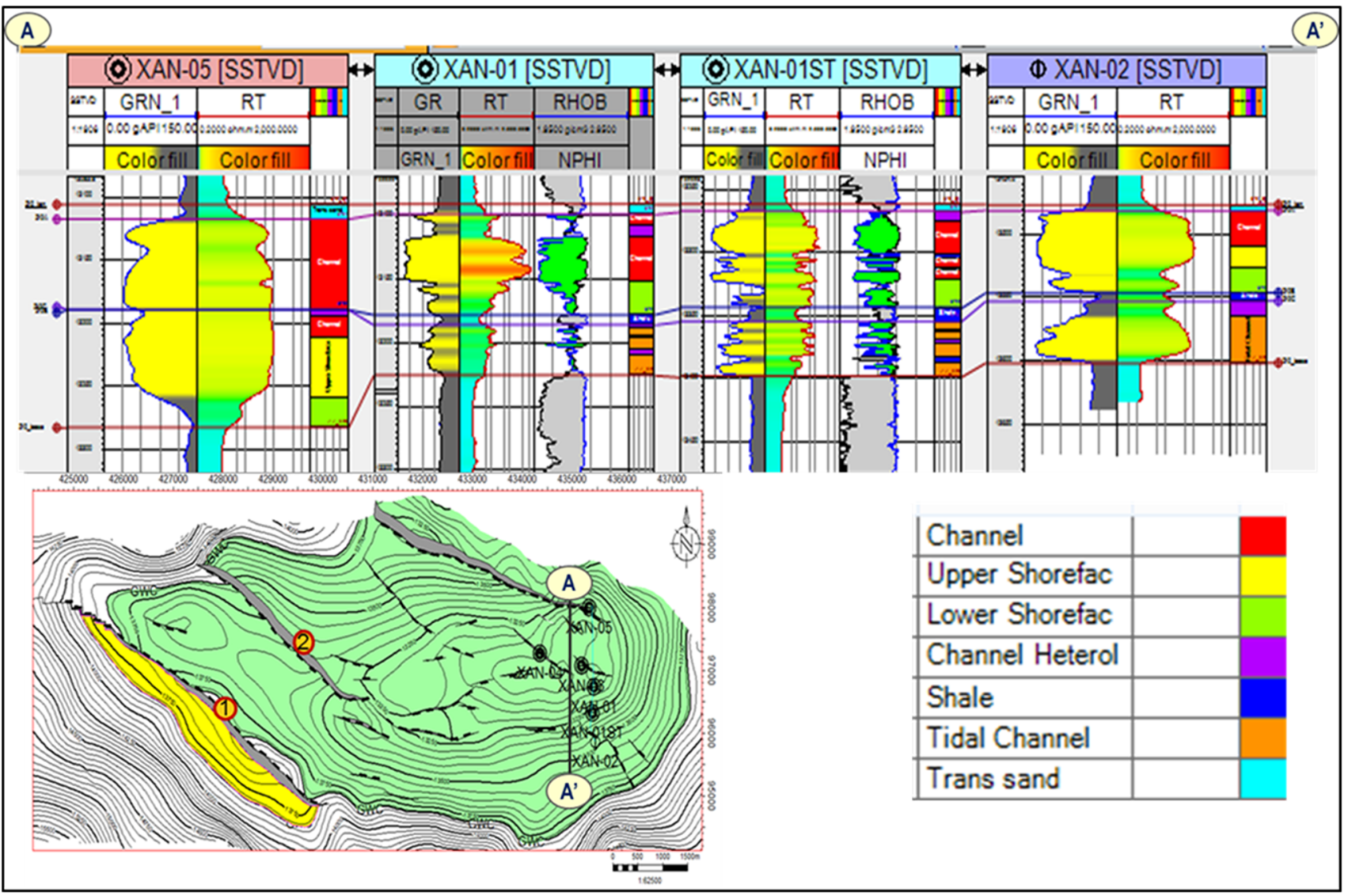

Fig. 9 A dip section $\left(A-A^{\prime}\right)$ along wells. The interpreted facies show the extent of the reservoir flow units. Northwards at XAN-05 the shale layer thins out

Fig. 10 Conceptual deposition model of internal facies description of available wells. The well points and facies at these points were relied upon to create the model. General Niger Delta depositional architecture was used showing the channel facies running in a north-south direction across the shoreface deposited east-west

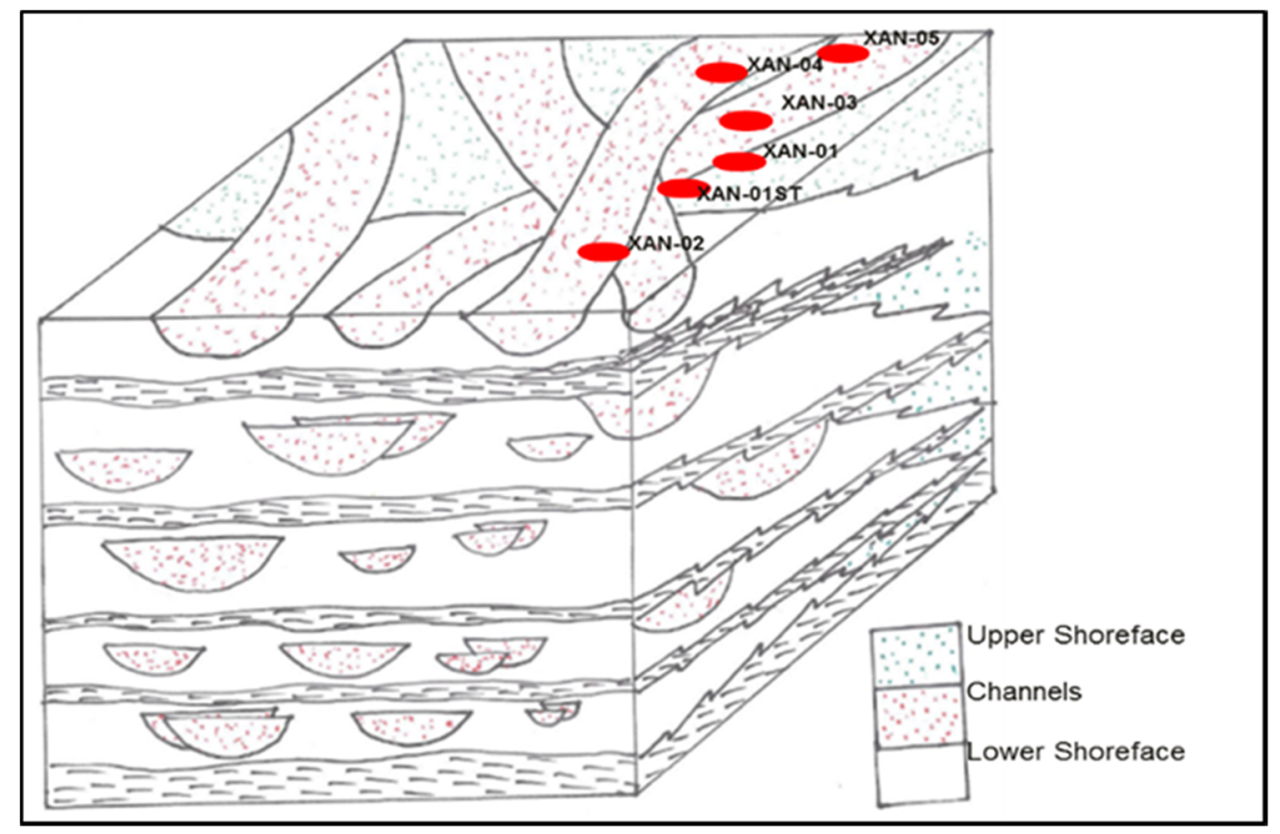

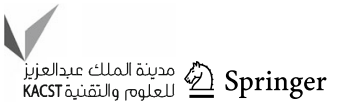




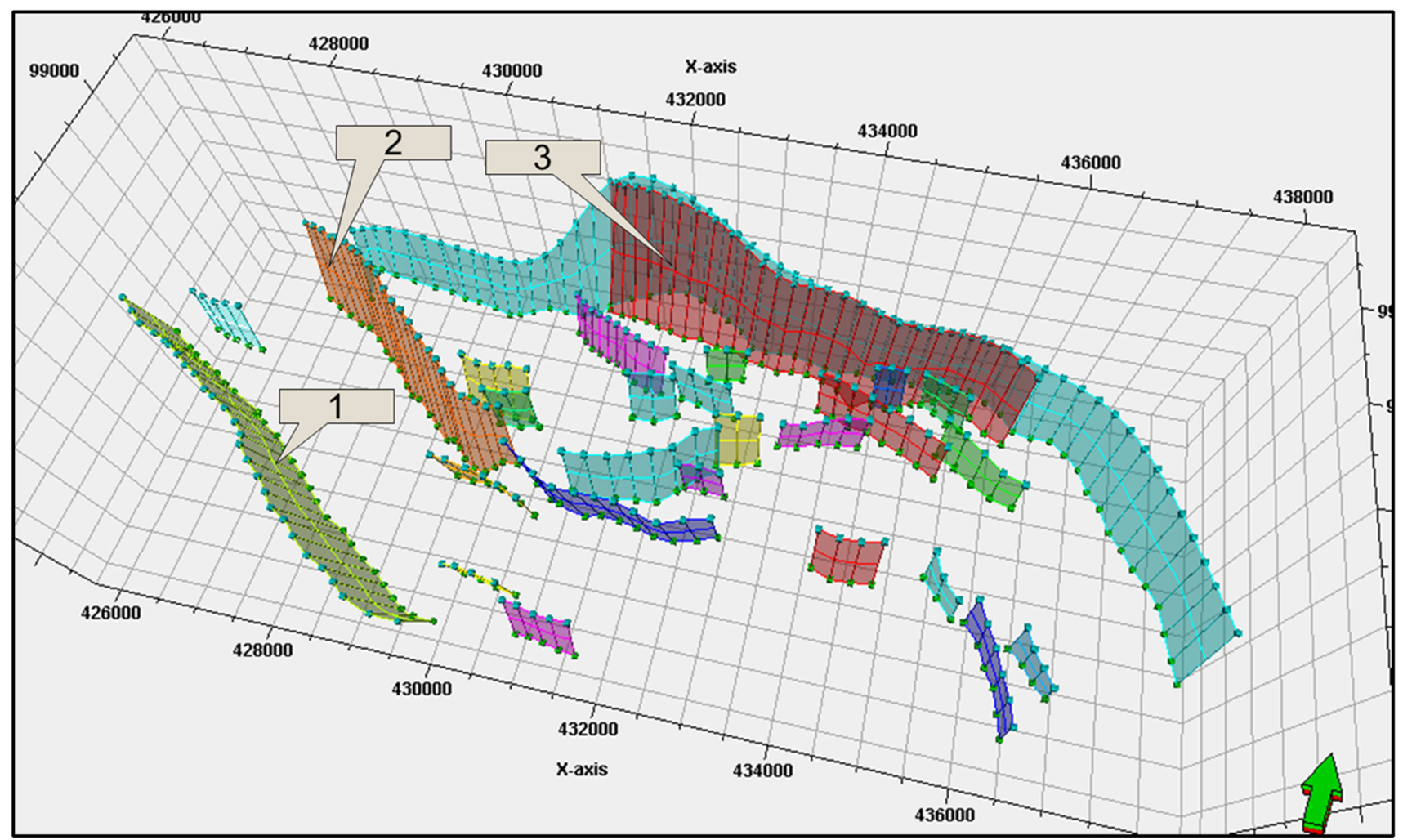

Fig. $113 \mathrm{D}$ fault model for Z-2 reservoir. Three major synthetic and antithetic intra-reservoir faults $(1,2$, and 3$)$ trend NW-SE. Major intrareservoir faults 1,2 , and 3 have large throws (120-50 ft)

Three system tracts HST, LST, and TST were recognized and mapped at the XAN-01 well (Fig. 6). HSTs occur between 12,632-11,652 and 10,343-9650-ft intervals. HSTs are characterized by intervals of coarsening and shallowing upwards, with both fluvial and deltaic sands near the top of the unit prograding laterally into neritic shales (Posamentier and Allen 1999; Posamentier et al. 1991). In the studied wells, the HST intervals are very thick and this can be attributed to high rates of subsidence, high sediment input, and instability associated with a slow rate of sea level rise.

LSTs are represented by a dominant basinward deposition of the shelf-edge during maximum regression and are characterized by deep-water gravity flows or traction processes within shelf-edge or canyon-head delta (Catuneanu et al. 2009). The sediments associated with LSTs recognized in the study area are the fluvial channel sands and slope floor fans. Siliciclastic sediments sometimes bypass the shelf and slope through the valleys and canyons and deposit in basin floor fans. The LST was not identified within the first depositional cycle capped by SB1 because the LST was deposited as a slope and basin floor fan basinwards. This is shown in the reconstructed depositional profile (Fig. 7). One major LST was interpreted between 9643 and $7769 \mathrm{ft}$.

The TSTs develop during sea level rise when sedimentation rate was unable to keep pace with the rate of sea level rise (Catuneanu et al. 2009; Richards et al. 1998; Posamentier and Allen 1999; Posamentier et al. 1991). Marine facies therefore retrograded landwards onto the shelf, and deltaic progradation ceased with the sands being trapped up dip in estuaries. TSTs are characterized by transition from upward shallowing to upward deepening and transgressive surface of erosion (TSE) on the shelf. The TSE usually occured at the base of the retrogradational parasequence stacks of the TSTs. Identified TSTs occur between 14,248-12,630, 11,637-10,350, and $7762-7476 \mathrm{ft}$.

These system tracts make up three depositional sequences. The first sequence is an incomplete sequence made up of a TST capped by MFS- 1 . The second sequence is also incomplete made up of a HST and TST capped by 

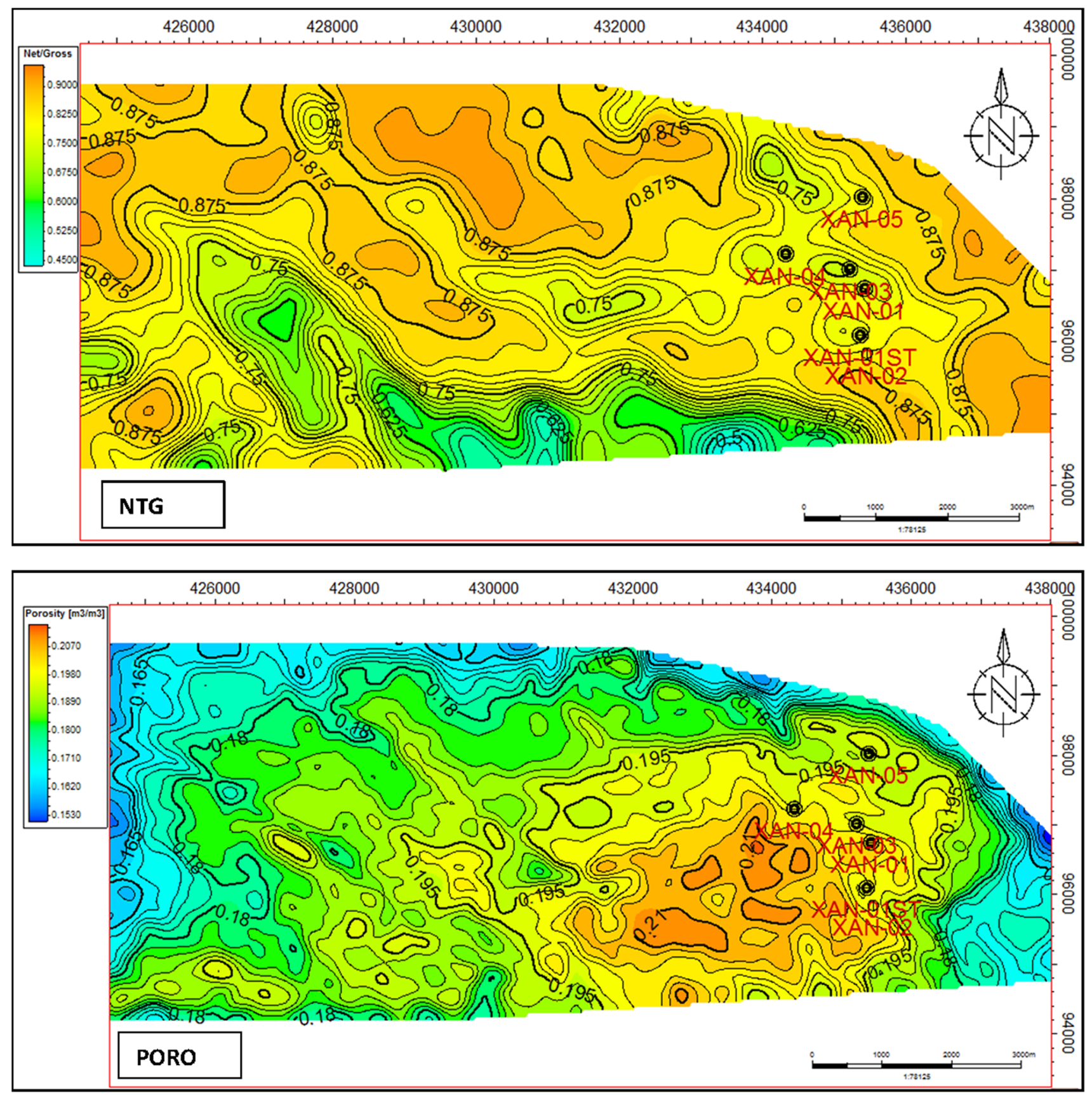

Fig. 12 The conception of the reservoir facies distribution based on NTG and porosity maps from seismic inversion shows good to fair sand development and porosity across the reservoir interval for the areas without well control

Table 1 Zonation and layer divisions of the facies and petrophysical models as modelled for the Z-2 reservoir

\begin{tabular}{lccc}
\hline Zone names & Zone divisions (layers) & Porosity range & Permeability range (mD) \\
\hline A & 1 & $0.05-0.10$ & $0.10-10.0$ \\
B & 30 & $0.25-0.30$ & $0.10-10,000$ \\
Shale & 1 & $0.00-0.10$ & $0.10-0.20$ \\
C & 20 & $0.05-0.30$ & $0.30-10,000$
\end{tabular}




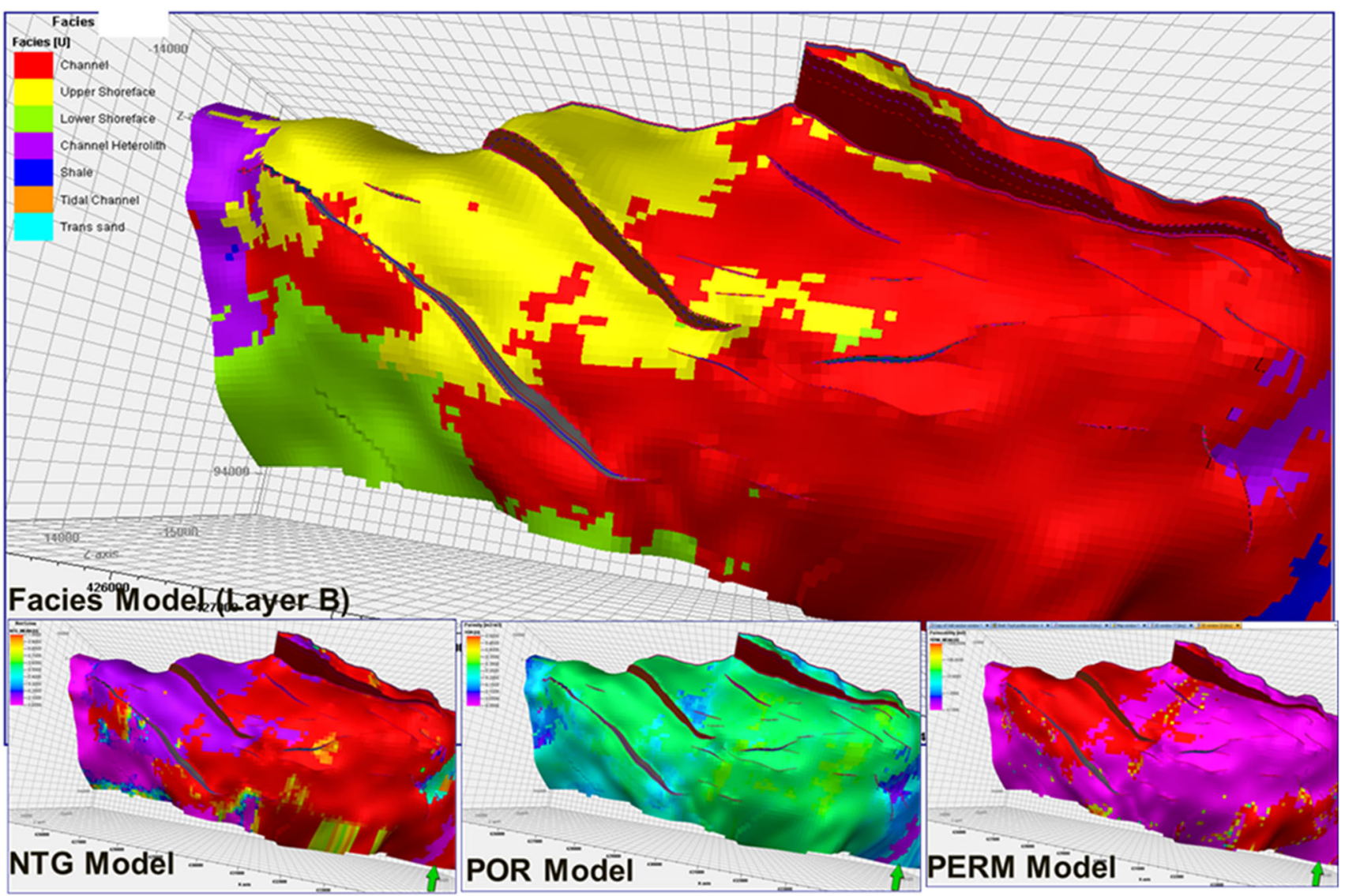

Fig. 13 Top of zone B at the Z-2 Reservoir showing modelled facies, NTG, porosity, and permeability. Variogram settings for the facies modelling is based on Niger Delta facies description. Dominant facies are channel and shoreface deposits. Shoreface facies extend in the east-west, while the channels cut through the shoreface in the northsouth direction. Petrophysical models were biased to the facies model and constrained with seismic inversion products (porosity and NTG maps)
MFS-2. The first and second sequences are separated by a ravinement surface. The third sequence is made up of a HST, LST, and TST, capped by a flooding surface at $7474 \mathrm{ft}$. The Z-2 occurs within the TST of the first depositional cycle. Z-2 reservoir shows a general increase in sand thickness from the base of the reservoir to its top indicating that Z-2 is a regressive deposit of the TST (Fig. 6), implying that the facies recognized in Z-2 are fairly continuous laterally across the reservoir.

\section{Facies description and flow unit identification}

Three flow zones, A, B, and C, were correlated using electrofacies description (Figs. 8, 9). Flow zone A is made up of transgressive sands attached to shoreface sandstones. Zone B is mostly composed of channel and upper shoreface (absent in XAN-01) and lower shoreface facies. The channels present blocky to fining upwards gamma ray signatures with low neutron and density readings, while lower shoreface is identified by coarsening-upward succession, made of thin bedded reservoir deposits, and sometimes connected to thick upper shoreface sandstones. The upper shoreface sandstones are characterized by cross- and planner bedding and coarsening-upward trends that are overlain by coastal plain channel fill sands. Zone $\mathrm{C}$ is mainly tidal channel facies made of thin bedded sandstones, distal storm beds, and shelf turbidites. Channel heteroliths exist in zones B and $\mathrm{C}$ associated with thick channel sands in a TST. A shale zone separates zones B and C (Fig. 9), and lithostratigraphic correlation shows that the shale zone thins out northwards. The identified facies were relied on to build a conceptual depositional model of the Z-2 to aid a fit-forpurpose reservoir model (Fig. 10). This conceptualization of the reservoir facies distribution was aided by the NTG and porosity maps (Fig. 8) showing well-developed sand bodies and porosity across the reservoir in areas without well control. 


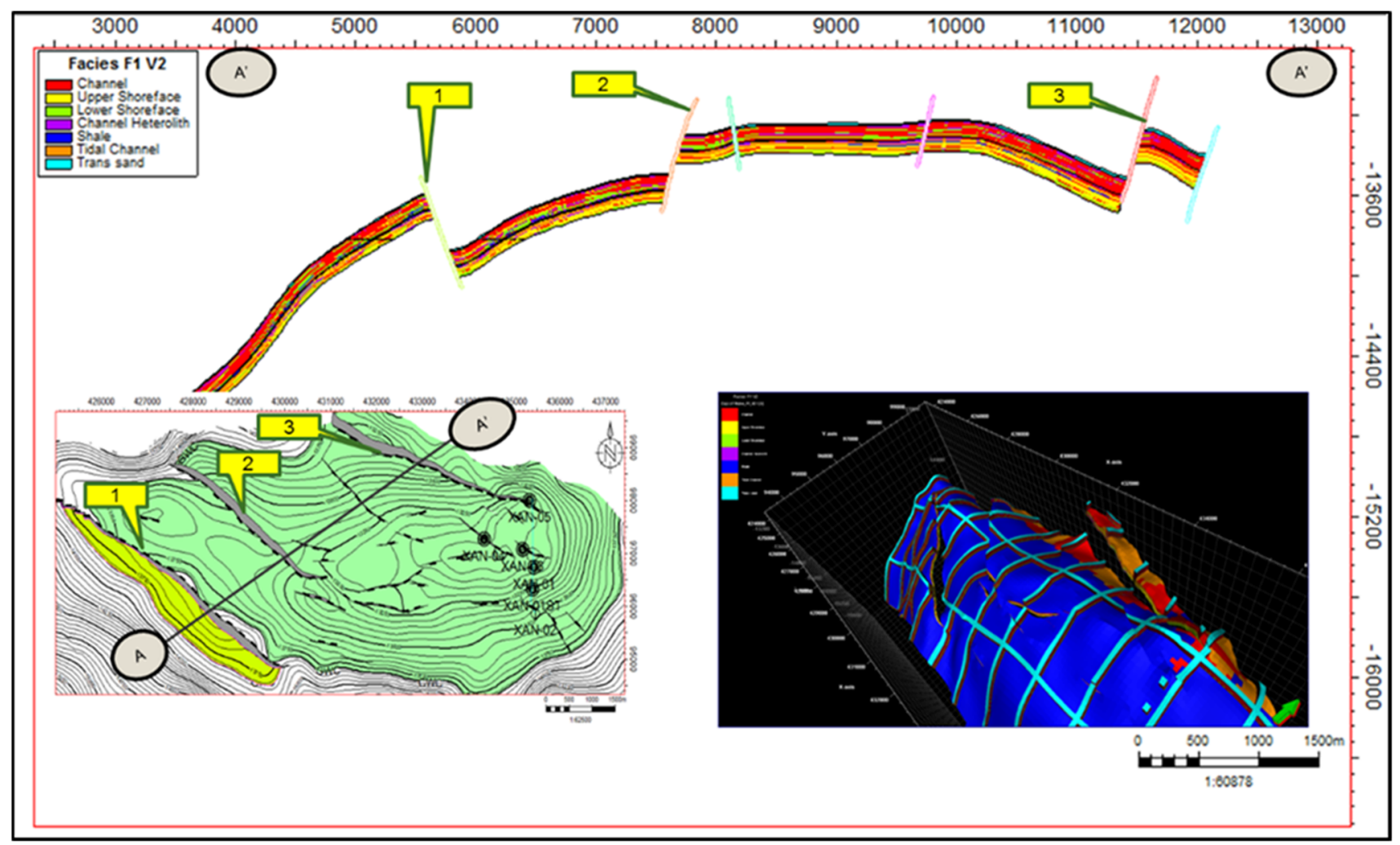

Fig. 14 A cross section of the facies model showing stratigraphic compartmentalization and a 3D view of the shale unit in a fence diagram. The shale unit will hamper vertical connectivity between the two interpreted flow units of the Z-2 reservoir

\section{Structural, facies, petrophysical modelling, and volume calculation}

Synthetic and antithetic faults were modelled for the Z-2 reservoir and all faults trend generally in the east-west direction. Three major intra-reservoir faults (faults 1,2 , and 3) were identified as faults likely to compartmentalize hydrocarbon accumulations during production (Fig. 11). This was based on their relatively large throws and positions. Faults 1, 2, and 3 have throws of about 50, 120, and $80 \mathrm{ft}$, respectively, and are located in the eastern part of the reservoir with no well control data.

The facies modelling is based on the sequence stratigraphic results and predicts good lateral sand development across the reservoir. This is in agreement with the conceptual depositional model, facies model, and the high net to gross indicated by the NTG and porosity maps (Fig. 12). The Z-2 is enclosed and sealed by thick layers of shale about $190 \mathrm{ft}$ (Fig. 8). The four major stratigraphic zones and seven facies (Fig. 9) were modelled with fifty-two minor layers (Table 1). Flow zones A, B, and $\mathrm{C}$ have average thicknesses of 54,18 , and $46 \mathrm{ft}$, respectively. The shale unit between units $\mathrm{B}$ and $\mathrm{C}$ is approximately $12 \mathrm{ft}$ and terminates just before fault 3 north of the reservoir. Modelled shoreface facies are extensive and trends east-west of the reservoir. The channels cut through the shoreface sands in the general north-south direction (Fig. 13).

Modelled porosity ranges from $<5$ to $30 \%$ through the zones. Modelled permeability ranges from 1 to $10,000 \mathrm{mD}$, while NTG ranges from about 0.1 to $>0.98$ through all zones (Table 1). The relatively high channel distribution in zones $\mathrm{B}$ and $\mathrm{C}$ is a major contributor to the high permeability and porosity of these zones. A fence diagram and an $\mathrm{A}-\mathrm{A}^{\mathrm{I}}$ cross section clearly show the extent of the shale unit and its pinch-out northwards of the reservoir (Fig. 14).

\section{Fault analysis}

Fault analysis shows that sand-on-sand juxtapositions exist at major intra-reservoir faults tips above the GWC (Fig. 15). It also shows that fault thickness range for juxtaposed areas for the three faults is $0-0.6 \mathrm{ft}$ (Fig. 16). Fault zone permeability for the same areas for fault 1 is $<1 \mathrm{mD}$. 


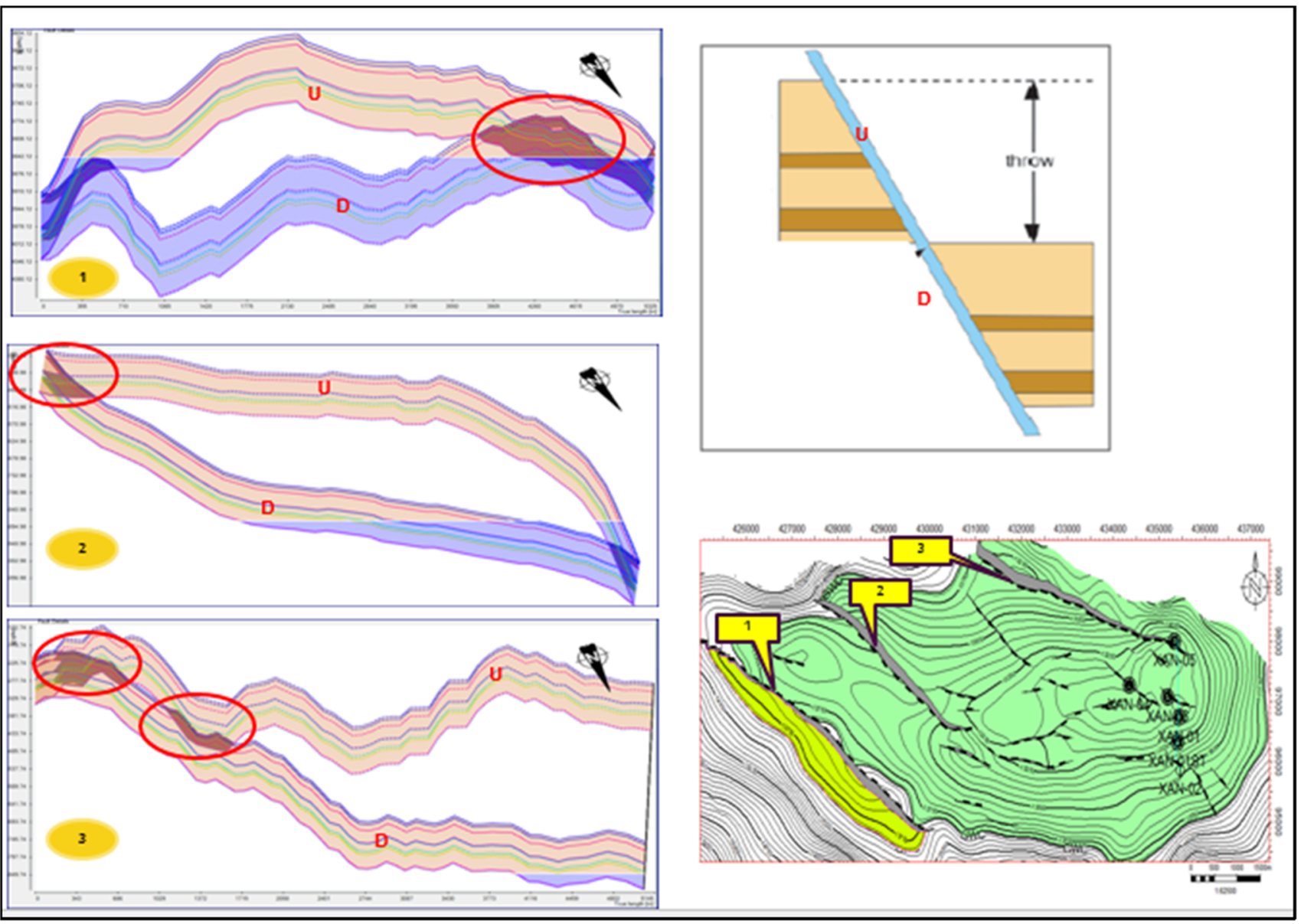

Fig. 15 Allan diagrams showing the upthrown $(U)$ fault and downthrown $(D)$ fault faces for faults 1,2 , and 3. The sand-on-sand juxtapositions (highlighted) are found at the fault tips. These sand-on-

However, a minor area of fault 2 is $>1 \mathrm{mD}$, while a relatively larger portion of the juxtaposed zone of fault 3 above $1 \mathrm{mD}$ is highlighted in Fig. 16. Shale gouge ratio (SGR) for all three faults ranges from 0 to $100 \%$. There is significantly higher percentage of areas below $35 \%$ in fault 3 than the others (Fig. 16).

\section{Conclusions}

This integrated analysis was successful in identifying the reservoir at risk of compartmentalization. The major intrareservoir shale between flow zones $\mathrm{B}$ and $\mathrm{C}$ can act as a vertical flow barrier at the southern regions of the Z-2. Fault zone thickness for the relevant intra-reservoir faults will not permit gas crossflow. Fault zone permeability for sand juxtaposed regions above the GWC provide areas for possible crossfault hydrocarbon flow

fault 1 may not allow gas crossflow while faults 2 and 3 may act as baffles to fluid flow. This is because of areas of faults 2 and 3 with permeability $>1 \mathrm{mD}$. These areas are $<20 \%$ of the sand-on-sand juxtaposition of these faults and also have SGR $<30 \%$. For fault 3, these areas are significantly larger. Consistently when compared to other faults, juxtaposed areas for fault 3 have less SGR and higher permeability. This shows that the major intrareservoir shale which thinned out before fault 3 (Fig. 14) is a major contributor to the permeability and SGR for the faults.

Accumulations $\mathrm{X}$ and $\mathrm{Y}$ are identified as areas that will likely become bypassed during production (Fig. 17). Fault 1 is interpreted to be sealing and completely isolates accumulation $\mathrm{X}$ (in yellow) from the rest of the reservoir (Fig. 18). Fault 2 may act as baffle to flow and may 

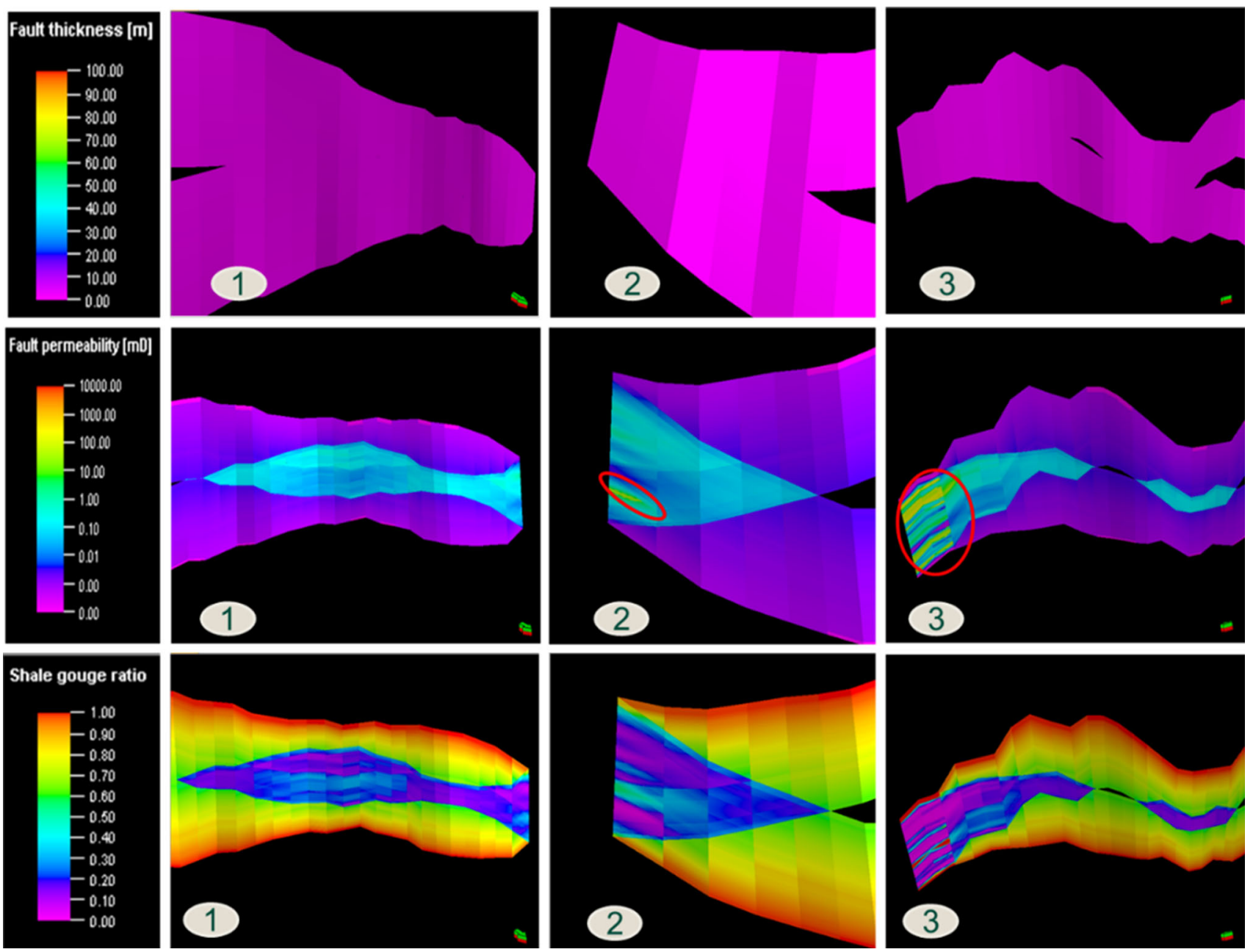

Fig. 16 Fault analysis of faults 1, 2, and 3 showing fault zone thickness fault permeability, and SGR. Fault thickness range for juxtaposed areas of faults 1,2 , and 3 is 0 to $0.6 \mathrm{ft}$ (will not permit crossflow), fault permeability for fault is $<1 \mathrm{mD}$ (will not permit crossflow), a minor area of fault 2 is $>1 \mathrm{mD}$, while a relatively larger portion of the juxtaposed zone of fault 3 is above $1 \mathrm{mD}$ (will permit crossflow), shale gouge ratio (SGR) for all three faults ranges from 0 to $100 \%$. There is significantly higher percentage of areas below $35 \%$ in fault 3 than the others

\section{Recommendations}

Z-2 has proved to be complex. Future well planning should be done in such a way as to access areas $\mathrm{X}$ and $\mathrm{Y}$ to avoid occurrence of bypassed hydrocarbon. Dynamic simulation should be carried out when production data become available to confirm effects of the intra-reservoir faults and the shale unit on gas crossflow. Extensive data gathering during production and development is essential to timely identify and properly define compartmentalizing complexities. Also integration of disciplines during early reservoir analysis is critical to a better understanding of the reservoir. 


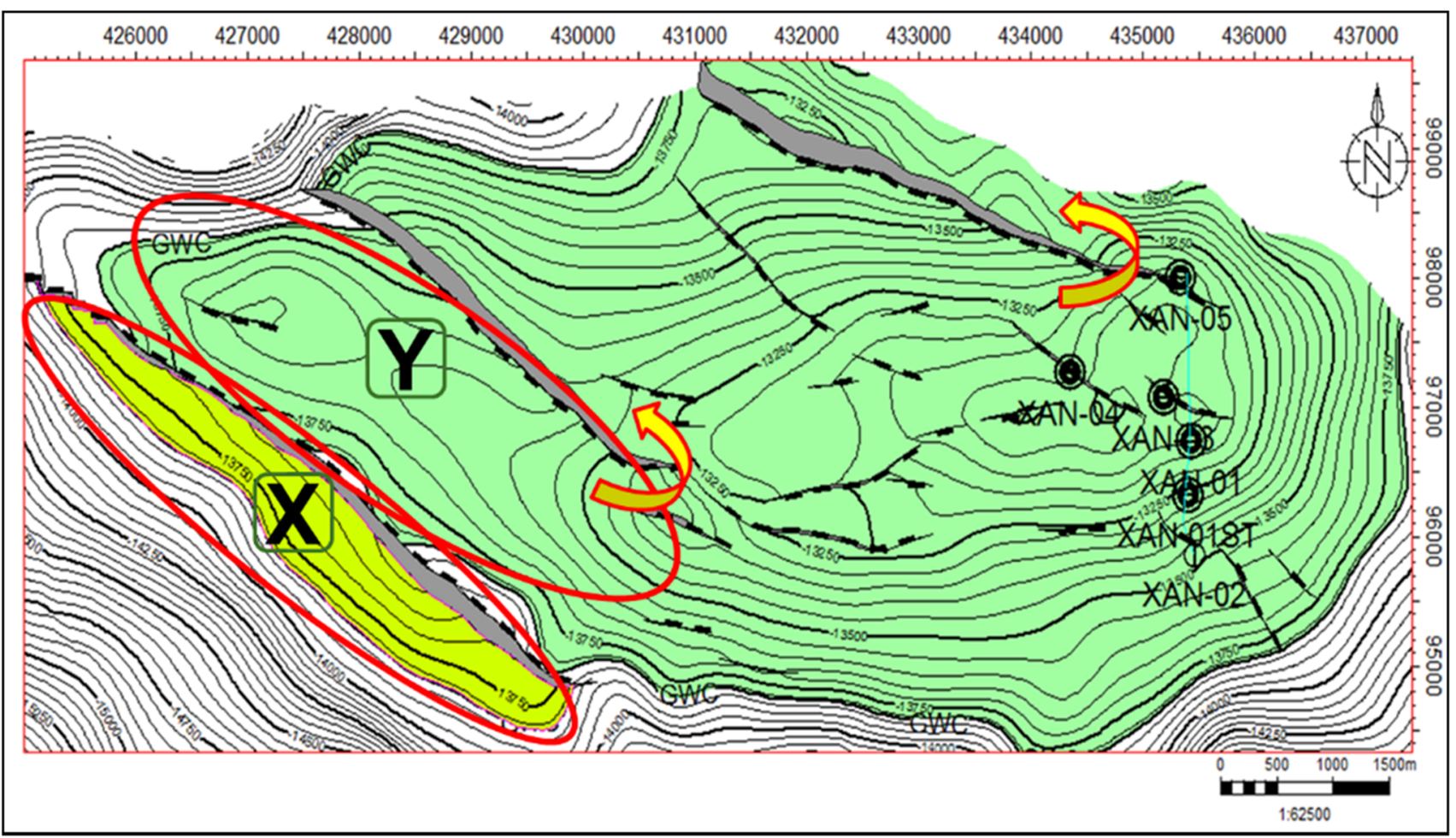

Fig. 17 Total GIIP for the field is calculated to be 1668 Bscf. $\mathrm{X}$ is likely completely isolated from the main reservoir by fault 1 , fault 2 may act as baffle to flow from and into Y, while fault 3 is not sealing.
Accumulations $\mathrm{X}$ and $\mathrm{Y}$ constitutes about $20 \%$ of the GIIP at risk of being lost to compartmentalization

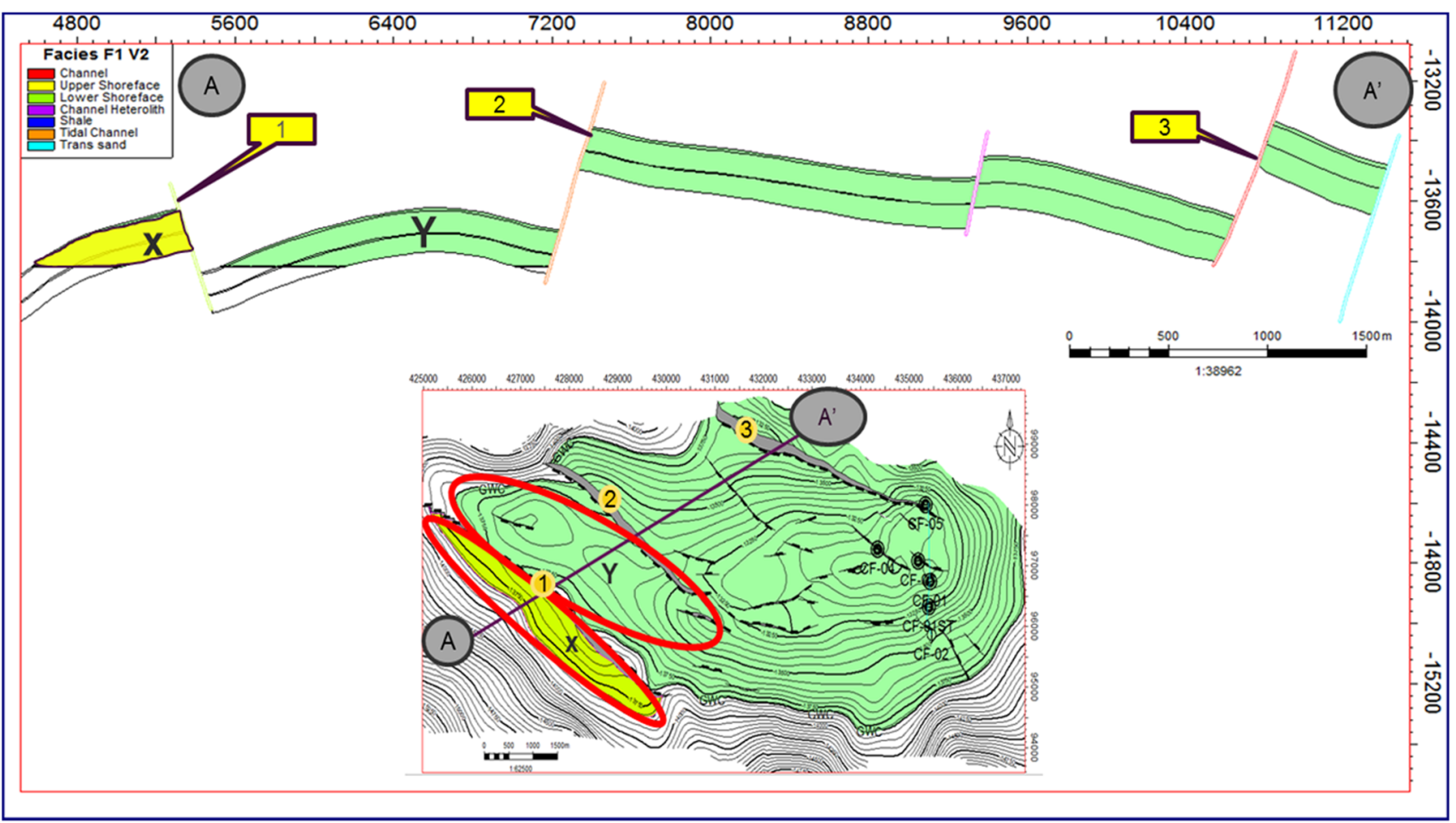

Fig. 18 A cross section showing possible areas for bypassed accumulation during production. They are highlighted south-west and of the reservoir in the map. The accumulations may be aided by major intra-reservoir faults 1 and 2 with high throws at the fault centre. Accumulation $\mathrm{X}$ is in yellow because it has not been tested by any well 
Acknowledgments Appreciations go to Prof. A.G. Onwuemesi and Dr. E.K. Anakwuba, and all the Geological Sciences Lecturers of Nnamdi Azikiwe University, Awka, for their academic input. Sincere gratitude also to Muyiwa Esho, George Kakayor, Ime Uyouko, Indutimi Preye, Efe Oghomienor, Edafe Efenovwe, Okiemute Amuboh, Inaingo Osuagwu, and the entire Export Gas Team of SPDC for their professional input to the success of this project. We remain grateful to the French Institute of Petroleum (IFP) for a grant administered through American Association of Petroleum Geologists (AAPG). This grant was invaluable to the completion of the project.

Open Access This article is distributed under the terms of the Creative Commons Attribution 4.0 International License (http:// creativecommons.org/licenses/by/4.0/), which permits unrestricted use, distribution, and reproduction in any medium, provided you give appropriate credit to the original author(s) and the source, provide a link to the Creative Commons license, and indicate if changes were made.

\section{References}

Avbovbo AA (1978) Tertiary Lithostratigraphy of Niger Delta. Am Assoc Pet Geol Bull 62:295-300

Aydin A, Eyal Y (2002) Anatomy of a normal fault with shale smear: implications for fault seal. Am Assoc Pet Geol Bull 86:1367

Barkved OP, Heavey P, Kjelstadli R, Kleppan T, Kristiansen TG (2003) Valhall field - still on plateau after 20 years of production: Society of Petroleum Engineers, SPE Paper 83957

Bretan P, Yielding G, Jones H (2003) Using calibrated shale gouge ratio to estimate hydrocarbon column heights. AAPG Bull 87:397-413

Caine JS, Evans JP, Foster CB (1996) Fault zone architecture and permeability structure. Geology 24:1025-1028

Catuneanu O, Abreu V, Bhattacharya JP, Blum MD, Dalrymple RW, Eriksson PG, Fielding CR, Fisher WL, Galloway WE, Gibling MR, Giles KA, Holbrook JM, Jordan R, Kendall CGSC, Macurda B, Martinsen OJ, Miall AD, Neal JE, Nummedal D, Pomar L, Posamentier HW, Pratt BR, Sarg JF, Shanley KW, Steel RJ, Strasser A, Tucker ME, Winker C (2009) Towards the standardization of sequence stratigraphy. Earth Sci Rev 92(1):1-33

Doust H, Omatsola E (1990) Niger Delta. In: Edwards JD, Santogrossi PA (eds) Divergent/passive margin basins, AAPG Memoir 48. American Association of Petroleum Geologists, Tulsa, pp 239-248

Foxford KA, Walsh JJ, Watterson J, Garden IR, Guscott SC, Burley SD (1998) Structure and content of the Moab fault Zone, Utah, USA, and its implications for fault seal prediction. In: Jones G, Fisher QJ, Knipe RJ (eds) Faulting, fault sealing and fluid flow in hydrocarbon reservoirs: geological society. Special Publications, London, pp 87-103

Gainski M, Macgregor AG, Freeman PJ, Nieuwland HF (2010) Turbidite reservoir compartmentalization and well targeting with 4D seismic and production data: Schiehallion Field, UK In: Jolley SJ, Fisher QJ, Ainsworth RB, Vrolijk PJ, Delisle SD (eds) Reservoir compartmentalization, vol 347. Geological Society of London Special Publications, pp 89-102

Hesthammer J, Bjørkum PA, Watts L (2002) The effects of temperature on sealing capacity of faults in sandstone reservoirs, examples from the Gullfaks and Gullfaks Sør fields, North Sea. Am Assoc Pet Geol Bull 86:1733-1751
Irving AD, Chavanne E, Faure V, Buffet P, Barber E (2010) An uncertainty modelling workflow for structurally compartmentalized reservoirs: geological society, vol 347. Special Publications, London, pp 283-299

Jolley SJ, Barr D, Walsh JJ, Knipe RJ (2007a) Structurally complex reservoirs: an introduction: geological society, vol 292. Special Publications, London

Jolley SJ, Dijk H, Lamens JH, Fisher QJ, Manzocchi T, Eikmans H, Huang Y (2007b) Faulting and fault sealing in production simulation models: challenges and impact of compartmentalization, Brent province, Northern North Sea. Pet Geosci 13:321-340

Jolley SJ, Fisher QJ, Ainsworth RB, Vrolijk PJ, Delisle S (2010) Reservoir compartmentalization: geological society, vol 347. Special Publications, London, pp 9-23

Knott SD (1993) Fault Seal Analysis in the North Sea. Am Assoc Pet Geol Bull 77:778-792

Krause FF, Collins HN, Nelson DA, Machemer SD, French PR (1987) Multiscale anatomy of a reservoir: Geological characterization of Pembina-Cardium Pool, westcentral Alberta, Canada. Am Assoc Pet Geol Bull 71:1233-1260

Kulke H (1995) Nigeria. In: Kulke H (ed) Regional petroleum geology of the world. Part II: Africa, America, Australia and Antarctica. Gebrüder Borntraeger, Berlin, pp 143-172

Leveille GP, Knipe RJ (1997) Compartmentalisation of Rotliegendes gas reservoirs by sealing faults, Jupiter Fields area, Southern North Sea. In: Ziegler K, Turner P, Daines SR (eds) Petroleum Geology of the Southern North Sea; Future Potential, vol 123. Geological Society of London Special Publications, pp 87-104

Onyeagoro UO, Naruk SJ, Dula FW, Garmezy LL (2001) Sensitivity analyses and prediction of dynamic fault behaviour: sensitivities of cross-fault flow to variations in fault rock properties. SIEP Report 2001-3125

Posamentier HW, Allen GP (1999) Siliciclastic sequence stratigraphy: concepts and applications. SEPM Concepts Sedimentol Paleontol 7:210

Posamentier HW, Erskine RD, Mitchum RM Jr (1991) Models for submarine-fan deposits within a sequence-stratigraphic framework. In: Weimer P, Link MH (eds) Seismic facies and sedimentary processes of submarine fans and turbidite systems, frontiers in sedimentary geology. Springer-Verlag, New York, pp 127-136

Richards M, Bowman M, Reading H (1998) Submarine-fan systems I: characterization and stratigraphic prediction. Mar Pet Geol 15:687-717

Short KC, Stauble AJ (1967) Outline of geology of the Niger Delta. Am Assoc Pet Geol Bull 51:761-779

Smith DA (1980) Sealing and non-sealing faults in Louisiana Gulf Coast salt basin. AAPG Bull 64:145-172

Van Wagoner JC, Mitchum RM Jr, Campion KM, Rahmanian VD (1990) Siliciclastic sequence stratigraphy in well logs, core, and outcrops: concepts for high-resolution correlation of time and facies. Am Assoc Pet Geol Methods Explor Ser 7:55

Wibberley CAJ, Yielding G, Di Toro G (2008) Recent advances in the understanding of fault zone internal structure: a review. In: Wibberley CAJ, Kurz W, Imber J, Holdsworth RE, Collettini C (eds) The internal structure of fault zones: implications for mechanical and fluid-flow properties: geological society, vol 299. Special Publications, London, pp 5-33

Yielding G, Freeman B, Needham DT (1997) Quantitative fault seal prediction. AAPG 81:897-917

Yielding G, Gretan P, Freeman B (2010) Fault seal calibration; a brief review: geological society, vol 347. Special Publications, London, pp 243-255 